\title{
Can dams affect the trophic structure of ichthyofauna? A long-term effects in the Neotropical region
}

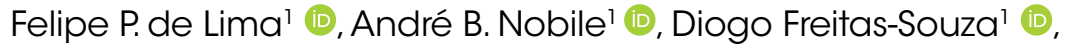 \\ Edmir D. Carvalho't \& Ana P.Vidotto-Magnoni2 (B)
}

\author{
1. Universidade Estadual Paulista - UNESP, Departamento de Morfologia, Instituto de Biociências, Rubião Júnior, s/nº, $18618-689$ Botucatu, SP, Brazil. \\ (fpl.limao@hotmail.com) \\ 2. Universidade Estadual de Londrina - UEL, Departamento de Biologia Animal e Vegetal, Rodovia Celso Garcia Cid - PR-445, Km 380, 86057-970 Londrina, PR, Brazil. \\ ${ }^{\dagger}$ In memoriam.
}

Received 21 July 2017

Accepted 24 June 2018

Published 17 September 2018

DOI 10.1590/1678-4766e2018030

ABSTRACT. Dams are considered an important source of modification upon the structure of aquatic communities and their reflexes are diverse on the fish fauna. Although there are several hydroelectric power plants in Brazil, the long-term effects on feeding activity of ichthyofauna are unknown. Thus, this study aimed to investigate the long-term effects of an old reservoir (fifty years) on the trophic dynamics of fish fauna. The diet of 20 fish species was analyzed, identifying 37 food items belonging to six trophic categories, which enable to create six trophic groups. The results found here suggests that throughout the creation of a reservoir, the trophic structure of the fish assemblages tend to reach trophic homeostasis, in which the fish community will be capable of exploring the most available food resources being maintained primarily by the items placed in the categories organic matter and fragments of fish and vegetal.

KEYWORDS. Feeding ecology; old dam; trophic stabilization; resource availability; fishes.

RESUMO. Podem barragens afetar a estrutura trófica da ictiofauna? Efeitos de longo prazo na Região Neotropical. As barragens são consideradas uma importante fonte de modificação na estrutura das comunidades aquáticas e seus reflexos são diversos na fauna de peixes. Embora existam várias usinas hidrelétricas no Brasil, os efeitos a longo prazo sobre a atividade de alimentação da ictiofauna são desconhecidos. Assim, este estudo teve como objetivo investigar os efeitos a longo prazo de um antigo reservatório (50 anos) sobre a dinâmica trófica da ictiofauna. A dieta de 20 espécies de peixes foi analisada, identificando 37 itens alimentares pertencentes a seis categorias tróficas, que possibilitaram a criação de seis grupos tróficos. Os resultados aqui encontrados sugerem que, ao longo da formação de um reservatório, a estrutura trófica das assembleias de peixes tende a atingir a homeostase trófica, na qual a comunidade de peixes será capaz de explorar os recursos alimentares mais disponíveis sendo mantidos principalmente pelos itens colocados nas categorias matéria orgânica e fragmentos de peixes e vegetais.

PALAVRAS-CHAVE. Ecologia alimentar; reservatório antigo; estabilização trófica; disponibilidade de recursos; peixes.

The action of dams upon the structure of aquatic communities is an important source of modification throughout the longitudinal and transversal gradients of these systems, bringing about distinct influences in the restructure of remaining communities (AgostinHo et al., 2007, 2015).

Hydrological disturbances arising from damming are determinants of reorganization of fish assemblages in the new environment. In this way, the availability of food supplies, the plasticity of feeding strategies and pre-adaptive characteristic of trophic guilds to lacustrine conditions are considered key elements for the establishment and accommodation of the ichthyofauna in reservoirs (PIET, 1998; RoDrigues-RuIZ, 1998).

In the initial phases of reservoirs formation, it is observed an intense heterotrophic activity (from items of allochthones origin) due to the flooding of the vegetation and soil that incorporate a series of resources into the environment, mainly vegetation and terrestrial invertebrates (BAXTER, 1977; Agostinho et al., 1999; CRIPPA \& HAHN, 2006). Thus, it is possible to establish that the impacts involved in the early stages of impoundments are directly related to changes in primary productivity caused by the release of nutrients from the decomposition of submerged organic matter (BALON, 1973; Petrere-Junior, 1996). This phase was designated by KIMMEL \& GROEGER (1986) as a trophic outbreak period in which it is observed that the fish assemblage shows an increase in the consumption of either terrestrial invertebrates (Albrecht \& CARAMASCHI, 2003; BALASSA et al., 2004) and terrestrial vegetation (CASSEMIRO, 2005). On the other hand, MonTEIRo et al. (2009) observed that in a small reservoir there were not significant alterations in the fish feeding dynamics, with only some subtle changes related to an increase of aquatic insects and algae consumption. 
After a few years, the reservoirs have a second moment, when it is possible to detect a process of trophic accommodation (CUNHA-SANTINO et al., 2013). This second stage is known as a period of trophic depression, when it is observed a sharp decrease in the nutrient availability, due to the sedimentation processes and water exportation through the turbines and spillways by the hydroelectric power-plant (HPP), causing the reservoir to achieve a new productivity level (AgostinHo et al., 1999, 2015; Williams et al., 1998). During the development of a reservoir, the fish assemblages begin to have intense random use of aquatic insects, terrestrial vegetation, organic matter, fishes, and crustaceans in their diet (MÉrona et al., 2001; LuZ-AgostinHo et al., 2006; Vidotto-Magnoni \& CARVAlho, 2009).

Agostinho et al. (2007) propose that changes in dammed environments tend to achieve trophic stabilization obeying a temporal perspective. This trophic accommodation is part of a third moment that refers to the status found in older reservoirs, defined in this paper as a period of ecological homeostasis. On this occasion, the biological processes resulting from drowning in marginal areas no longer have great influence on the trophic structure of fish assemblages. This approach is still little known scientifically as, in most
Neotropical reservoirs, the operating time is less than twentyfive years and so is not possible yet the establishment and definition of the processes occurring at this stage LowEMCCONNELl (1999).

As Brazilian reservoirs age, it becomes feasible to develop studies involving the ichthyofauna and its feeding strategies in environments that have long been dammed, and such information may permit the consolidation of the knowledge pertaining to the third phase that is equivalent to the trophic balance in reservoirs. Thus, the hypothesis of this work is that Jurumirim reservoir, which has been operating for more than five decades, has already passed by the trophic stabilization process, being their community stable in terms trophic guilds.

\section{MATERIAL AND METHODS}

The Jurumirim reservoir was formed with the construction of the hydroelectric power plant (HPP) "Armando Laydner", which started at the end of the 1950's and began to operate in 1962. This dam is considered as large size (HenRY \& NogueIRA, 1999), and divided into three zones: lotic, transition and lentic (NogueIRA et al., 1999; TundisI, 1993) (Fig. 1; Tab. I).

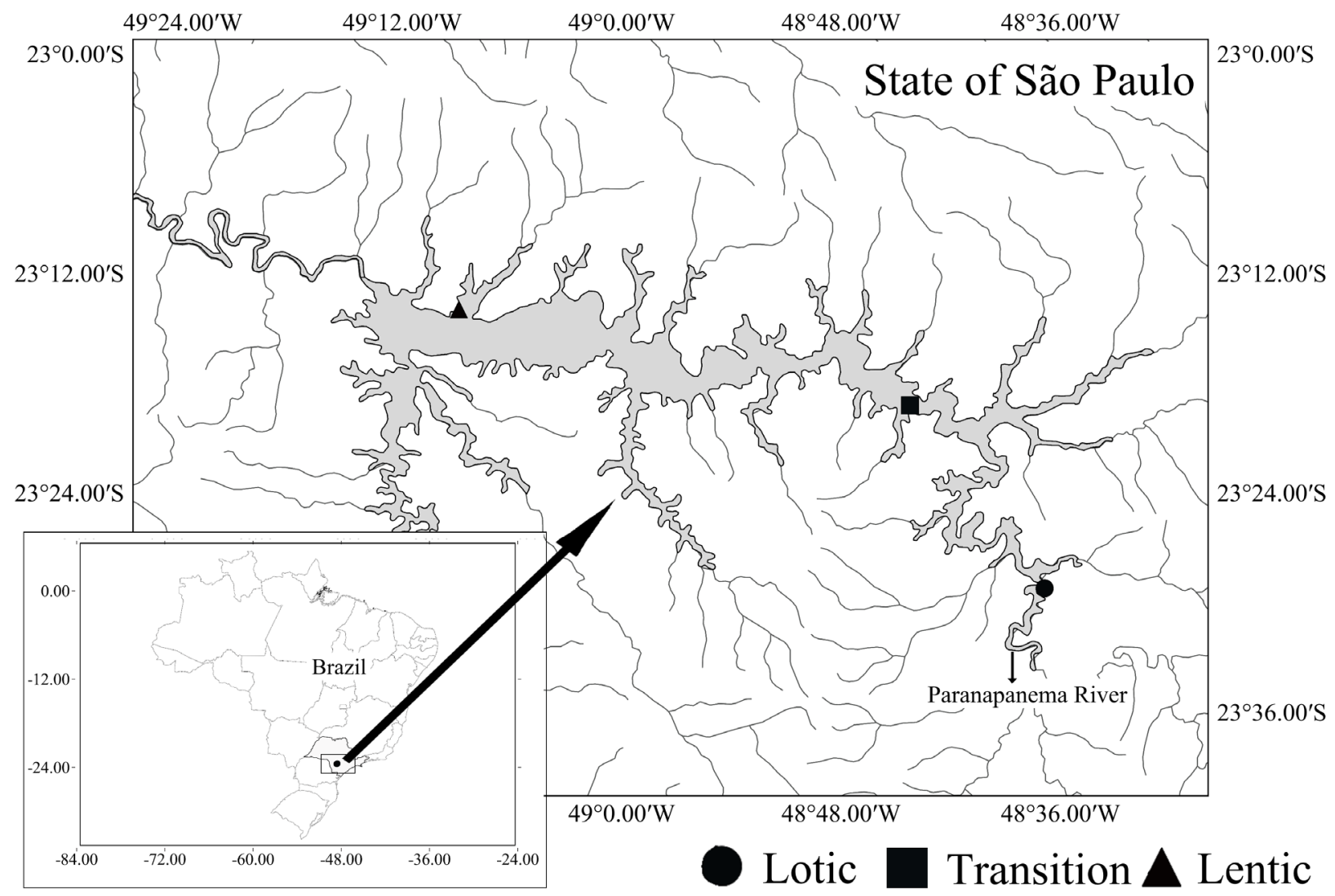

Fig. 1. Map of Jurumirim Reservoir (Upper Paranapanema River, state of São Paulo, Brazil) indicating the three samplings zones. 
Tab. I. Environmental characteristics of the sampling zones in Jurumirim Reservoir, Upper Paranapanema river, state of São Paulo, Brazil.

\begin{tabular}{cll}
\hline Stretch & \multicolumn{1}{c}{ Locality } & \multicolumn{1}{c}{ Environmental characteristics } \\
\hline Lotic & $\begin{array}{l}\text { Angatuba municipality/ Paranapanema River } \\
\text { channel. }\end{array}$ & $\begin{array}{l}\text { Important ecotone between fluvial and lacustrine environments (HENRY, 2003) subject to } \\
\text { the effects of the flooding pulse (NEIFF, 1999) very attenuated by the water mass of the } \\
\text { reservoir body that works as a buffering agent (HENRY et al., 2006). }\end{array}$ \\
Transition & $\begin{array}{l}\text { Paranapanema municipality/ Close to the } \\
\text { mouth of three tributaries (Jacu, Santo Inácio } \\
\text { and Veados rivers), in the old bank of Para- } \\
\text { napanema River (SAMPAIO, 1944). }\end{array}$ & $\begin{array}{l}\text { Semilentic's water with a few aquatic macrophytes and high number of decaying trees. } \\
\text { Presents oscillation of the water level imposed by the impoundment and the carrying of } \\
\text { allochthons matter and sediment from Paranapanema river and some tributaries. }\end{array}$ \\
Lentic & $\begin{array}{l}\text { Arandu municipality/ Close to the impoun- } \\
\text { dment zone in the main channel of the } \\
\text { Jurumirim Reservoir HPP }\end{array}$ & $\begin{array}{l}\text { Lentic environment and deep water up to 30 m (HENRY, 1992). Sediment composed by } \\
\text { sand and gravel, a few aquatic macrophytes in the shore area, and some remaining forest. }\end{array}$ \\
\hline
\end{tabular}

Six fish samplings were carried out (ICMBio license $\mathrm{n}^{\mathrm{o}}$ 15549-1) bimonthly from April/2010 to February/2011, in three sampling sites, representing the three zones of reservoir: lotic (1), transition (2) and lentic (3). Fish were passively caught with gillnets, with mesh varying from 3 to $14 \mathrm{~cm}$ between opposite knots, that were installed at dusk and set aside at dawn, performing 14 hours of exposition. Voucher specimens were deposited in the Fish Collection of the Laboratory of Fish Biology and Genetics (LBP) of the Department of Morphology, Institute of Biosciences of UNESP - Botucatu and in the Museu de Zoologia da Universidade Estadual de Londrina (MZUEL).

For stomach content analyses were selected species that showed at least four individuals with some food content. The stomach contents were analyzed in the lab with the aid of a stereomicroscope and eventually under an optic microscope. The food items were weighted using analytical scale and afterward analyzed by the Alimentary Index (\%Ai) that was proposed by KaWAKami \& VAZZOLER (1980).

The food items identified were grouped in categories and the fish species were classified into trophic groups following the Alimentary Index values $(\geq 50 \%$ of the index in a determined trophic category). The data on the fish species feeding were ordered with the different trophic categories and submitted to a Detrended Correspondence Analysis (DCA) (Hill \& GaUCH, 1980). To do so, the values of the total weight of the food items transformed were used (constant summed one and logarithmic) and the analysis were done in the software PC-ORD - 5 (MCCUNE \& MEFFord, 2006). The importance (in numeric abundance and biomass) of the trophic guilds was also estimated using the percentage of the total capture of specimens since in all stretch the capture efforts were always standardized.

The assessment of resources availability used was made with the weight of all items present in the stomach contents of all species in each studied stretch. WINEMILLER \& Kelso-Winemiller (1996) premise that the species clusters analyzed explore every eatable resource found in the environment. Considering that not all the stomachs had their content analyzed and the number of the ones analyzed for each species was not proportional to the participation in the sample, the weight was corrected according the equation proposed by GASPAR DA LuZ et al. (2001).

Finally, the trophic interaction networks have been set up with the ichthyofauna and diet data of the species (Tab. III) using the Pajek software, version 4.01a (BATAGELJ $\&$ MrVAR, 1998). The parameters calculated for the nets were: number of trophic species (fish species), number of resources consumed (food items), resource density (number of resources per species), number of trophic links (lines in nets indicating interactions between resource-consumer), density of trophic links (number of connections per species).

\section{RESULTS}

It was analyzed 20 fish species distributed in three orders and nine families, with a record of the nonnative species Cichla monoculus Spix \& Agassiz, 1831 (Tab. II).

The diet analysis was carried out with the identification of the food items of 999 stomachs. It was recorded 37 food items in which 29 were considered autochthonous and eight allochthonous, distributed in six trophic categories (Vegetal matter: Spirogyra sp., Desmidium aptagonum, Cyanophyceae, Zygnemaphyceae, Chlorophyceae, Plant fragment, Seeds; Detritus: Amorphous organic matter; Fishes: Unidentified fish, Characiformes, Gymnotus sp., scales; Insects: Aquatic: unidentified exoskeleton fragments, Chironomidae (Larvae and pupae), Odonata - Gomphidae and other families, Hemiptera, Trichoptera, Ephemeroptera, Ceratopogonidae, Chaoboridae; and Terrestrial: unidentified exoskeleton fragments, Diptera adults, Coleoptera adults, Hymenoptera, Orthopteran; Crustaceans: Macrobrachium sp. (larvae and adults), Copepoda, Ostracoda; Other: Bivalvia, Gastropoda, Araneae, Tecameba, Acari). Thus, six trophic groups were identified in values of the Alimentary Index (\%AIi) (Tab. III).

According to the Detrended Correspondence Analysis (DCA), the axis one and two explained 49.29\% of the relation among fish species and the trophic categories. The total variance ("Inertia") found for this analysis was 2.41 and the auto-values of the axis one and two were 0.82 and 0.36 respectively. The DCA demonstrated that 


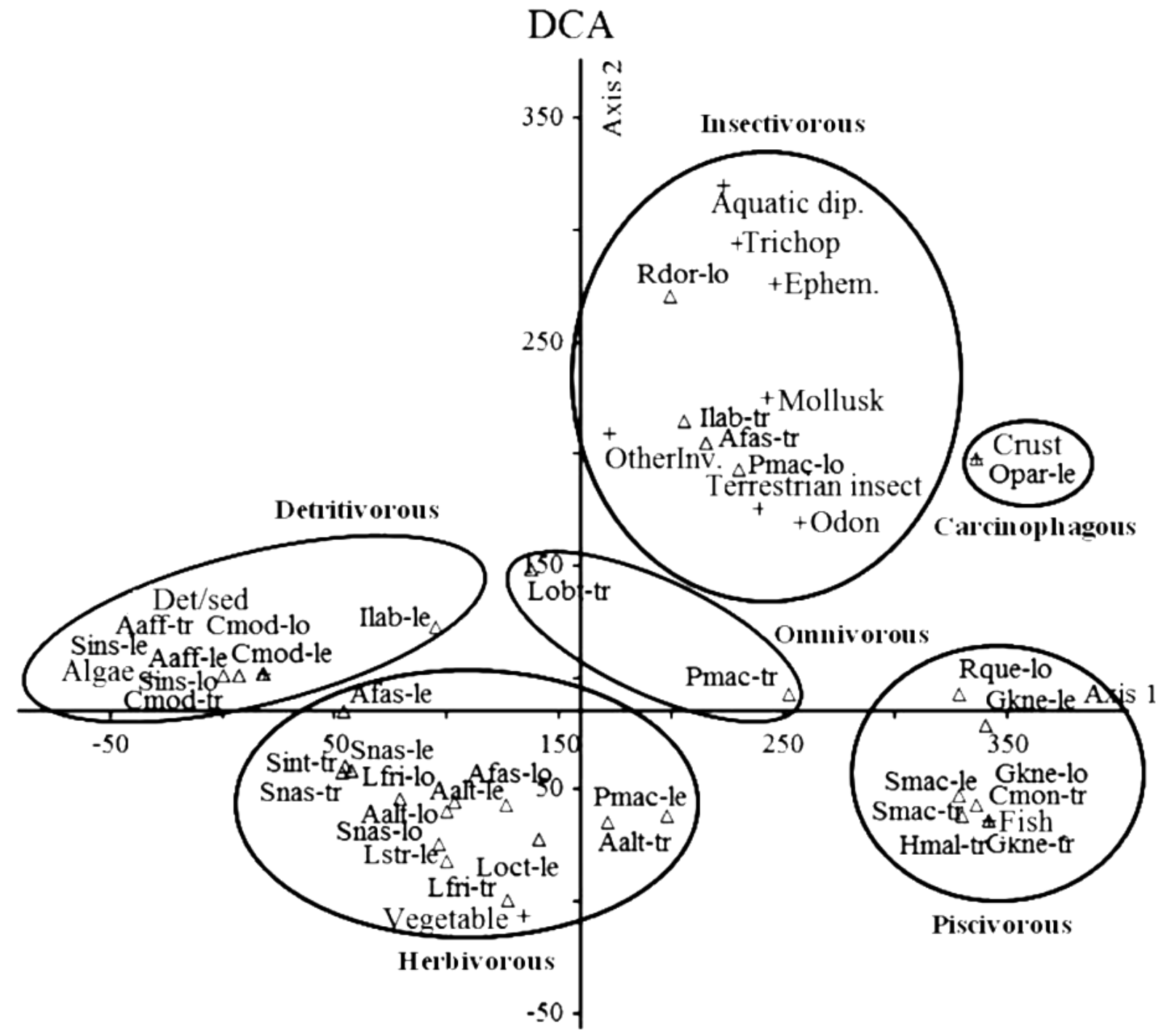

Fig. 2. Detrended Correspondence Analysis (DCA) (biplot) considering the fish species of each stretch and the different trophic categories in Jurumirim Reservoir, Upper Paranapanema River, state of São Paulo, Brazil. Acronym of the species in the Table III.

the fish species were related with the trophic categories respecting the evaluation performed based on the values of the alimentary index, evidencing six trophic guilds in the DCA graphic analysis (Fig. 2). The acronyms of the main resources and trophic categories used in de Figure 2 are presented below: (1) Insect categories - Chironomidae: Aquatic dip.; Trichoptera: Trichop.; Ephemeroptera: Ephem.; Odonata: Odon.; (2) Detritus category - Det/ Sed.; (3) Vegetal matter category - Vegetable and Algae; (4) Crustaceans category - Crust; (5) Other category OtherInv; (6) Fishes category - Fish pie.

In terms of abundance and biomass, it was observed relevant contribution of species with feeding habit considered specialist, as detritivorous, herbivorous, and piscivorous. In the zones lotic and lentic, both in number and biomass, there were a dominance of the herbivorous guild while in the stretch transition, the detritivorous guild showed greater contribution considering these parameters (Fig. 3). Together, the three guilds considered as trophic specialists, correspond with more than $70 \%$ of the numeric abundance and biomass in the three zones.

The availability of resources among zones was similar, however the proportion among them, inferred from the weight of the sets of the gastric contents analyzed, showed that the availability varied according to the type of resource (Fig. 4). Thus, in the lotic stretch, the most available resources were vegetal matter (41.87\%) followed by organic matter $(36.38 \%)$, and fish (16.37\%). For the stretch transition, organic matter was the most used resource $(47.57 \%)$ followed by fish $(27.78 \%)$ and vegetal matter $(19.71 \%)$. In the lentic stretch, vegetal matter was the most representative item $(35.36 \%)$ followed by fish $(32.18 \%)$ and organic matter $(25.56 \%)$.

Among the three zones sampled, although lotic zone had fewer items consumed, it was the point with higher density of resources. However, lentic zone presents greater density of connections between them (Tab. IV). 
Tab. II. List of the fish species and number of stomachs analyzed in the three zones (lotic, transition and lentic) of Jurumirim Reservoir, located in the Upper Paranapanema river, state of São Paulo, Brazil (Non-native*).

\begin{tabular}{|c|c|c|c|c|}
\hline \multirow{2}{*}{ ORDER / Family / Species } & \multirow{2}{*}{ Voucher } & \multicolumn{3}{|c|}{ Number of analyzed stomachs } \\
\hline & & Lotic & Transition & Lentic \\
\hline \multicolumn{5}{|l|}{ CHARACIFORMES } \\
\hline \multicolumn{5}{|l|}{ Characidae } \\
\hline Astyanax lacustris (Lütken 1875) & MZUEL 5676 & 5 & 30 & 35 \\
\hline Astyanax fasciatus (Cuvier, 1819) & MZUEL 5669 & 10 & 20 & 42 \\
\hline Galeocharax knerii (Steindachner, 1879) & LBP 13302 & 7 & 7 & 10 \\
\hline Oligosarcus paranensis Menezes \& Géry, 1983 & MZUEL 5677 & - & - & 5 \\
\hline Serrasalmus maculatus Kner, 1858 & MZUEL 5665 & - & 34 & 69 \\
\hline \multicolumn{5}{|l|}{ Curimatidae } \\
\hline Cyphocharax modestus (Fernández-Yépez, 1948) & LBP 13297 & 21 & 77 & 17 \\
\hline Steindachnerina insculpta (Fernández-Yépez, 1948) & LBP 13313 & 39 & 4 & 26 \\
\hline \multicolumn{5}{|l|}{ Erythrinidae } \\
\hline Hoplias malabaricus (Bloch, 1794) & MZUEL 5662 & - & - & 4 \\
\hline \multicolumn{5}{|l|}{ Parodontidae } \\
\hline Apareiodon affinis (Steindachner, 1879) & LBP 13316 & - & 38 & 85 \\
\hline \multicolumn{5}{|l|}{ Anostomidae } \\
\hline Leporinus friderici (Bloch, 1794) & LBP 13304 & 9 & 5 & - \\
\hline Megaleporinus obtusidens (Valenciennes, 1837) & LBP 13318 & - & 6 & - \\
\hline Leporinus octofasciatus Steindachner, 1915 & LBP 13294 & - & - & 6 \\
\hline Leporinus striatus Kner, 1858 & LBP 13300 & - & - & 5 \\
\hline Schizodon intermedius Garavello \& Britski, 1990 & LPB 13311 & - & 58 & - \\
\hline Schizodon nasutus Kner, 1858 & MZUEL 5678 & 15 & 79 & 57 \\
\hline \multicolumn{5}{|l|}{ SILURIFORMES } \\
\hline \multicolumn{5}{|l|}{ Pimelodidae } \\
\hline Iheringichthys labrosus (Lütken, 1874) & LBP 13306 & - & 11 & 21 \\
\hline Pimelodus maculatus LaCépède, 1803 & LBP 13317 & 6 & 18 & 64 \\
\hline \multicolumn{5}{|l|}{ Heptapteridae } \\
\hline Rhamdia quelen (Quoy \& Gaimard, 1824) & LBP 13310 & 5 & - & - \\
\hline \multicolumn{5}{|l|}{ Doradidae } \\
\hline Rhinodoras dorbigny (Kner, 1855) & LBP 7446 & 30 & - & - \\
\hline \multicolumn{5}{|l|}{ PERCIFORMES } \\
\hline \multicolumn{5}{|l|}{ Cichlidae } \\
\hline Cichla monoculus Spix \& Agassiz, 1831 & MZUEL 5671 & - & 19 & - \\
\hline
\end{tabular}

Herbivorous @Detritivorous

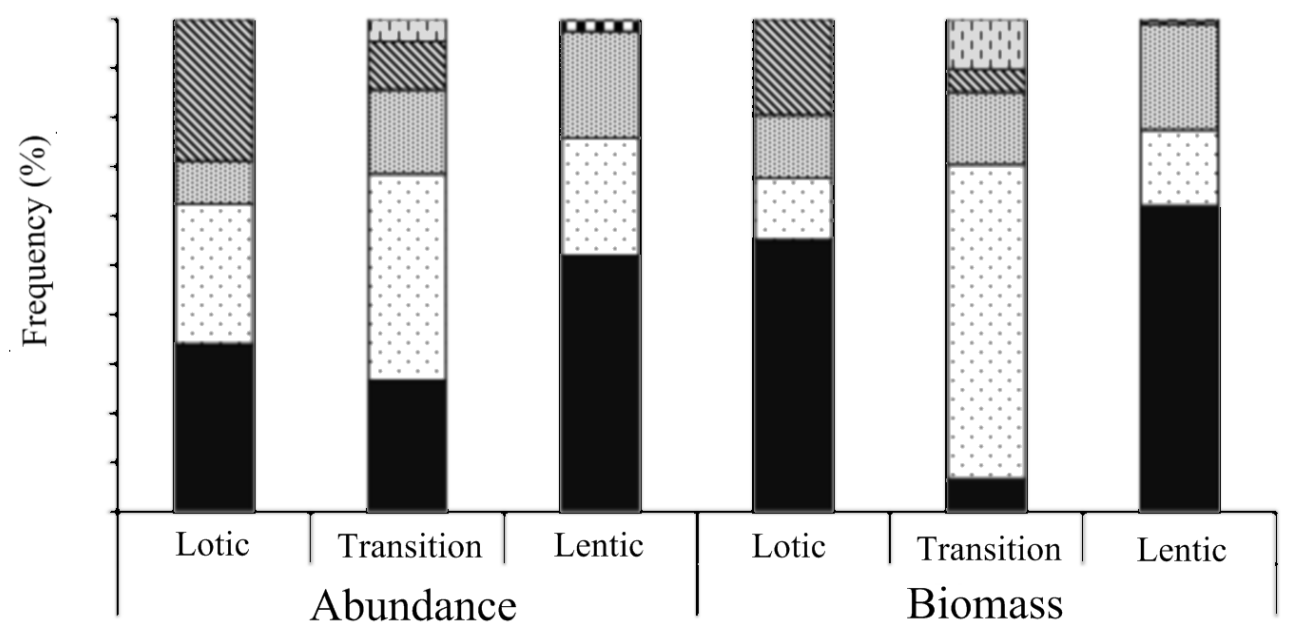

Fig. 3. Importance of trophic guilds (in numeric abundance and biomass) by stretch (lotic, transition, and lentic) of Jurumirim Reservoir, Upper Paranapanema River, state of São Paulo, Brazil. 
Tab. III. Trophic group determined by the main food categories, highlighted in bold, consumed by the fish species in three zones (1,2, and 3) of Jurumirim Reservoir, Paranapanema river, Upper Paranapanema River, state of São Paulo, Brazil.

\begin{tabular}{|c|c|c|c|c|c|c|c|c|c|}
\hline \multirow[b]{2}{*}{ Species } & \multirow[b]{2}{*}{ Acronym } & \multirow[b]{2}{*}{ Stretch } & \multirow[b]{2}{*}{ Trophic Group } & \multicolumn{6}{|c|}{ Trophic Category } \\
\hline & & & & Vegetal & Insects & Fishes & $\begin{array}{l}\text { Organic } \\
\text { Matter }\end{array}$ & $\begin{array}{c}\text { Crustaceans } \\
\text { decapods }\end{array}$ & $\begin{array}{l}\text { S Other } \\
\text { invertebrates }\end{array}$ \\
\hline \multirow{4}{*}{ Astyanax lacustris } & \multirow{4}{*}{ Alac } & Lotic & Herbivorous & 95.87 & 4.13 & - & - & - & - \\
\hline & & Transition & Herbivorous & 71.54 & 20.26 & 8.20 & - & - & - \\
\hline & & Lentic & Herbivorous & 86.19 & 8.39 & 0.29 & 4.77 & 0.36 & - \\
\hline & & Lotic & Herbivorous & 87.90 & 5.67 & - & 6.43 & - & - \\
\hline \multirow[t]{2}{*}{ Astyanax fasciatus } & \multirow[t]{2}{*}{ Afas } & Transition & Insectivorous & 47.34 & 50.51 & - & 2.15 & - & - \\
\hline & & Lentic & Herbivorous & 87.77 & 5.68 & - & 5.90 & - & 0.66 \\
\hline \multirow{2}{*}{ Apareiodon affinis } & \multirow{3}{*}{ Aaf } & Transition & Detritivorous & 11.60 & - & - & 88.40 & - & - \\
\hline & & Lentic & Detritivorous & 19 & - & - & 81 & - & - \\
\hline \multirow{3}{*}{ Cyphocharax modestus } & & Lotic & Detritivorous & 0.10 & - & - & 99.90 & - & - \\
\hline & \multirow[t]{2}{*}{ Cmod } & Transition & Detritivorous & 0.21 & - & - & 99.79 & - & - \\
\hline & & Lentic & Detritivorous & - & - & - & 99.75 & - & 0.25 \\
\hline \multirow[t]{2}{*}{ Cichla kelberi } & \multirow[t]{2}{*}{ Ckel } & Transition & Piscivorous & - & 0.01 & 99.99 & - & - & - \\
\hline & & Lotic & Piscivorous & - & - & 100 & - & - & - \\
\hline \multirow[t]{2}{*}{ Galeocharax knerii } & \multirow[t]{2}{*}{ Gkne } & Transition & Piscivorous & - & - & 100 & - & - & - \\
\hline & & Lentic & Piscivorous & - & - & $\mathbf{5 7 . 2 0}$ & - & 42.80 & - \\
\hline Hoplias malabaricus & Hmal & Transition & Piscivorous & - & 0.07 & 99.93 & - & - & - \\
\hline \multirow{2}{*}{ Iheringichthys labrosus } & \multirow{2}{*}{ Ilab } & Transition & Insectivorous & 27.77 & 58.61 & - & 8.17 & 3.24 & 2.20 \\
\hline & & Lentic & Detritivorous & 2.66 & 28.32 & 0.23 & 59.61 & 0.55 & 8.63 \\
\hline \multirow{2}{*}{ Leporinus friderici } & \multirow{2}{*}{ Lfri } & Lotic & Herbivorous & 69.25 & - & 0.15 & 30.60 & - & - \\
\hline & & Transition & Herbivorous & 97.73 & - & - & 2.27 & - & - \\
\hline Megaleporinus obtusidens & Mobt & Transition & Omnivorous & 34.87 & 17.15 & - & 46.47 & - & 1.51 \\
\hline Leporinus octofasciatus & Loct & Lentic & Herbivorous & 83.98 & 12.18 & - & 0.88 & - & 2.95 \\
\hline Leporinus striatus & Lstr & Lentic & Herbivorous & 94.89 & - & - & 5.11 & - & - \\
\hline Oligosarcus paranensis & Opar & Lentic & Carcinophagous & - & 2.26 & - & - & 97.74 & - \\
\hline \multirow{3}{*}{ Pimelodus maculatus } & \multirow{3}{*}{ Pmac } & Lotic & Insectivorous & 10.25 & $\mathbf{5 8 . 3 0}$ & - & - & - & 31.45 \\
\hline & & Transition & Omnivorous & 22.60 & 9.60 & 28.20 & 25.03 & 4.95 & 9.62 \\
\hline & & Lentic & Herbivorous & 55.61 & 15.21 & 18.57 & 7.04 & 0.89 & 2.69 \\
\hline Rhinodoras dorbignyi & Rdor & Lotic & Insectivorous & 1.59 & 91.58 & - & 3.06 & - & 3.78 \\
\hline Rhamdia quelen & Rque & Lotic & Piscivorous & 5.48 & 1.04 & 62.93 & 0.49 & 30.06 & - \\
\hline \multirow{2}{*}{ Serrasalmus maculatus } & \multirow{2}{*}{ Smac } & Transition & Piscivorous & - & 0.19 & 99.81 & - & - & - \\
\hline & & Lentic & Piscivorous & 0.25 & - & 99.75 & - & - & - \\
\hline & & Lotic & Detritivorous & 0.12 & - & - & 99.88 & - & - \\
\hline Steindachnerina insculpta & Sinc & Lentic & Detritivorous & 1.06 & - & - & 98.94 & - & - \\
\hline Schizodon intermedius & Sint & Transition & Detritivorous & 49.45 & - & - & 50.55 & - & - \\
\hline & & Lotic & Herbivorous & 87.18 & - & - & 12.82 & - & - \\
\hline Schizodon nasutus & Snas & Transition & Detritivorous & 35.81 & - & - & 64.19 & - & - \\
\hline & & Lentic & Herbivorous & 63.76 & - & - & 36.24 & - & - \\
\hline
\end{tabular}

Tab. IV. Trophic interaction networks parameters based on assemblages and the resources consumed by fish in Jurumirim Reservoir, Upper Paranapanema River, state of São Paulo, Brazil.

\begin{tabular}{lccc}
\hline & Stretch 1 & Stretch 2 & Stretch 3 \\
\hline Trophic species & 10.0 & $\mathbf{1 4 . 0}$ & 13.0 \\
Resource & 31.0 & $\mathbf{3 8 . 0}$ & 34.0 \\
Density resources & $\mathbf{3 . 1}$ & 2.7 & 2.6 \\
Trophic linkages & 78.0 & $\mathbf{1 4 0 . 0}$ & 136.0 \\
League density trophic & 7.8 & 10.0 & $\mathbf{1 0 . 5}$ \\
\hline
\end{tabular}

In the lotic zone, the resources most used by the assemblage were vegetal matter and detritus, used by seven species, and terrestrial insect and seed, both being consumed by five species. The species that concentrated the largest number of items (14) was Astyanax fasciatus (Cuvier, 1819). Rhinodoras dorbigny (Kner, 1855), Rhamdia quelen (Quoy
\& Gaimard, 1824) and Pimelodus maculatus LaCépède, 1803 consumed respectively 13,11 and 10 items in this environment (Fig. 5). In transition zone, it was observed that the items with the highest number of links are vegetal matter, Chironomidae larvae, detritus and aquatic insect with respectively 10, 10, 9 and 8 links in the chain. The species that used a greater number of means were $P$. maculatus, $A$. fasciatus, Schizodon intermedius Garavello \& Britski, 1990 and A. fasciatus, which 19, 16, 16 and 13 items consumed respectively (Fig. 6). Finally, in lentic zone of the items with the highest number of interactions were detritus (10), vegetal matter and aquatic insect, both with 8 links. Regarding the fish species, those called to the largest number of items were P. maculatus (24), Astyanax altiparanae Garutti \& Britiski, 2000 (15) and Iheringichthys labrosus (Lukten, 1874) (14) (Fig. 7). 


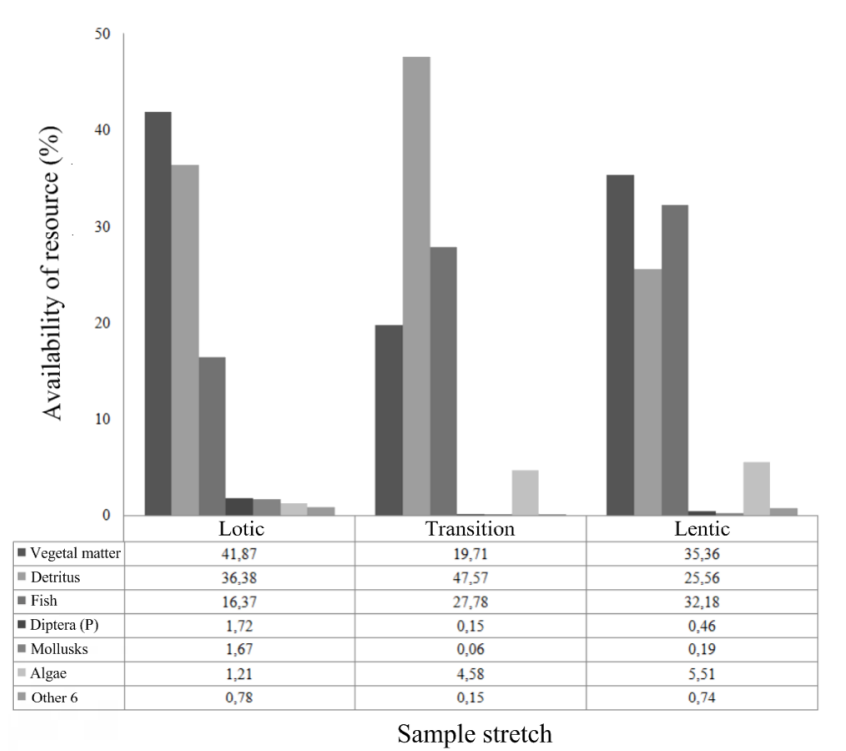

Fig. 4. Proportion of the resources used by the species in the three studied zones in Jurumirim Reservoir, Upper Paranapanema River, state of São Paulo, Brazil: 1, Lotic; 2, Transition; 3, Lentic.

\section{DISCUSSION}

The time required by fish community structure to achieve certain degree of stability after reservoir closure may vary widely, and there is no consensus about it (PetrereJUNIOR, 1996). There are evidences of stabilization of the fish abundance and species richness between 15 and 40 years after a reservoir is formed (MoL et al., 2007; ORSI \& BRITTON, 2014) but, little is said about the trophic structuring.

The trophic structure of a reservoir is the reflection of the interaction between the quality/quantity of food available in the environment and the degree of morphological/behavioral constraints showed by the species, though this last is liable to ontogenetic variations (GASPAR DA LuZ et al., 2001).

The short-term effects of impoundments upon fish feeding dynamic have already been widely studied (HAHN et al., 1997, 1998; AlBRECHT \& CARAMASCHI, 2003; LuZAgostinho et al., 2006; Novaes et al., 2004; SCHNEIDER et al., 2011), being their reflections discussed in the review made by HAHN \& FUGI (2007). This review gives us a pattern of changes that occur in the food chain of fish pre and post damming remedying the absence of previous information about the damming of the HPP Jurumirim before and immediately after your formation.

As seen, the literature about questions involving trophic reservoirs is wide. However, when the diet of fish is associated with the formation time, the literature draws only perspectives about the effects of dams on the feed composition of fish communities. In this context, authors like AgOSTINHO et al.(2007) and Araujo-Lima et al.(1995) emphasize that the fish community should, as time goes by, be maintained by autochthonous items, as observed in the networks of trophic interactions formed by the species evaluated in the Jurumirim reservoir, thus enhancing the effects of trophic accommodation on the local ichthyofauna.
Among the few studies that approach the longterm effects of reservoir upon trophic dynamics of fish assemblages, it was observed that in old reservoirs, although of small size, fish still take advantage of allochthones items in their diet (DiAs et al., 2005). On the other hand, in old medium and large reservoirs, mainly autochthonous items and vegetal debris maintain the food chain of fish species (ABelHa et al., 2005; BenNEMANn et al., 2011; Ribeiro et al., 2014; Souto et al., 2017).

Such items are always found in available and constant in the vast majority of hydroelectric systems (Souto et al., 2016). These factors (availability and consistency) can be considered as the basic elements that explain the processes of trophic accommodation of fish assemblages in these systems.

Possibly, the use of this resource might be a reflection of the ichthyofaunistic adjustment to the hydrological regime that most of the reservoirs are submitted (Souto et al., 2016). These data corroborate with other systems analyzed, as well as with the perspectives drawn for old reservoirs (ARAUJOLima et al., 1995; ABelHa et al., 2005; Dias et al., 2005; Agostinho et al., 2007; Bennemann et al., 2011).

The trophic specialization was observed here presenting dominance of the guild of herbivores, both in abundance and biomass in lotic and lentic zones. GouLDING (1980) reports that herbivory is largely influenced by spatial and temporal variations, mainly in flooded areas or under the influence of dams.

XImenes et al. (2011) corroborate our findings, reporting in the Ibicuí River that the composition and distribution of species that compose the trophic guilds are dependent on several complex and interactive factors. Among these factors, these authors emphasized the habitat structure, food availability, fish assemblage richness, environmental factors such as physical and morphological characteristics, and the time that the reservoir is formed.

Spanned the timeframe evaluated in this study, it is considered that the trophic structure of fish assemblages in old reservoirs is reflective of various components mentioned above and especially the relationship between the remaining fish species in the process of colonization and the time of formation of this reservoir.

Agostinho et al. (2015) reports that species with pre-adaptive characteristics favorable to the consumption of a big resources variety are considered favored in the colonization phase of reservoirs. Thus, in new reservoir, normally the most abundant trophic guild is omnivorous, composed by opportunist and trophic generalist species.

In Jurumirim Reservoir, which is old, the majority species presented specialized feeding habit. This feeding structure is considered a reflection of trophic accommodation of species in the environment throughout the time that the reservoir was formed. MÉRONA et al. (2003) corroborates this tendency in the fish assemblages.

The results presented in this study are considered as a general overview of trophic accommodation of fish assemblages in old reservoirs, in which the ichthycenosis are 

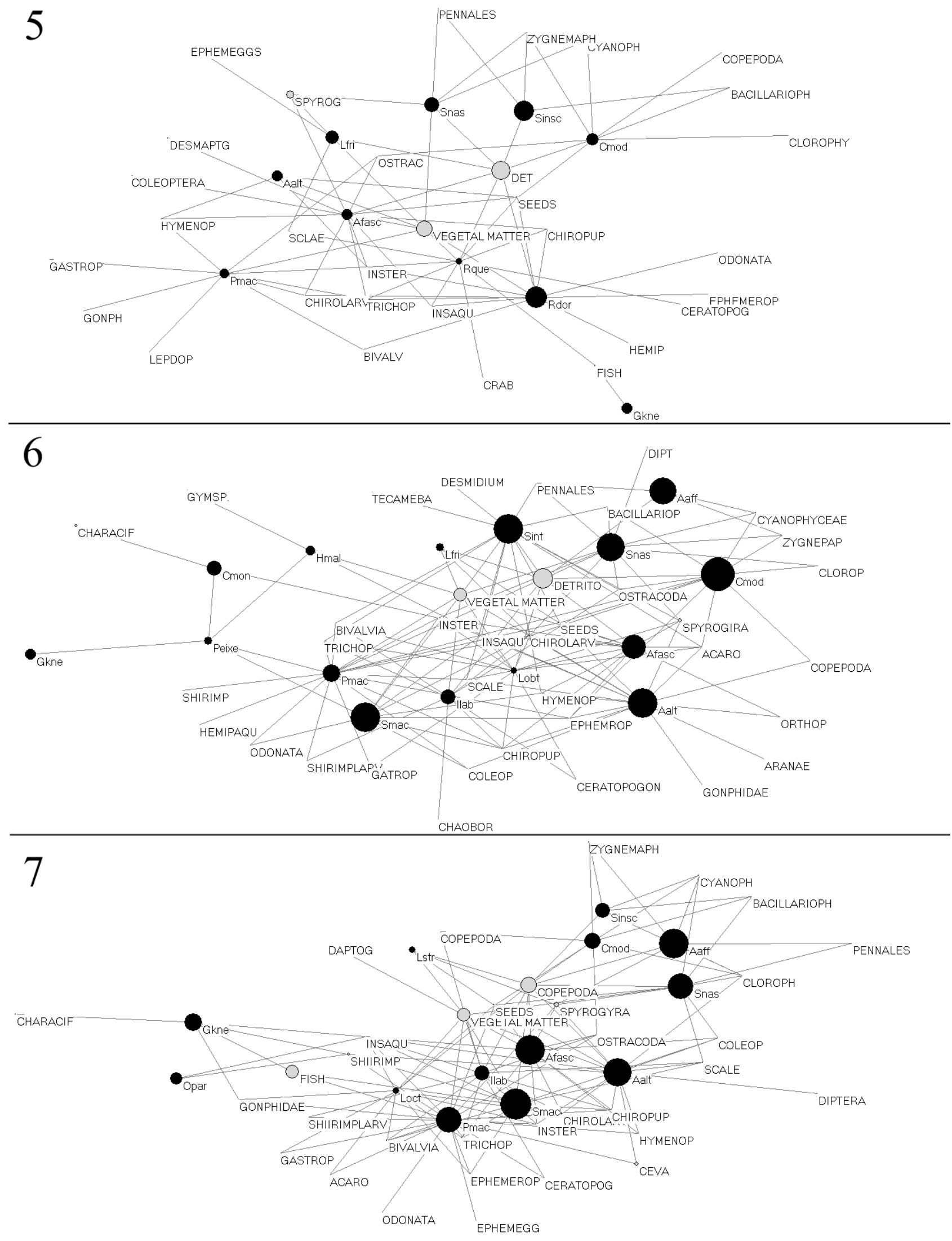

Figs 5-7. Trophic interactions networks built with fish species (black) and resources consumed (gray): Fig. 5, Stretch 1 (lotic); Fig. 6, Stretch 2 (transition) and Fig. 7, Stretch 3 (lentic) in Jurumirim Reservoir, Upper Paranapanema River, state of São Paulo, Brazil. 
able to exploit the most available food resources throughout the formation of the reservoirs, finding a way to avoid overlapping food and competition for resources. Thus, the length of time of formation of the reservoirs reflects in the ichthyofauna, making the remaining fish assemblages show a tendency to express specificity in their diet, with the common groups defined as trophic specialist mainly piscivorous, detritivorous, and herbivorous.

Acknowledgements. The authors wish to thanks to CNPq (ABN: 140360/2011-5; DFS: 141526/2015-7) and Capes (FPL: 141941/20120; APVM: PNPD 3005/2010) for scholarships.

\section{REFERENCES}

Abelha, M. C. F.; Goulart, E. \& Peretti, D. 2005. Estrutura trófica e variação sazonal do espectro alimentar da assembleia de peixes do reservatório de Capivari, Paraná, Brasil. In: Rodrigues, L.; Thomaz, S. M.; Agostinho, A. A. \& Gomes, L. C. eds. Biocenoses em Reservatórios: padrões espaciais e temporais. São Carlos, RiMa Editora, p.197-209.

Agostinho, A. A.; Miranda, L. E.; Bini, L. M.; Gomes, L. C.; Thomaz, S. M. \& SuzUKI, H. I. 1999. Patterns of Colonization in Neotropical Reservoirs, and Prognoses on Aging. In: TUNDISI, J. G. \& STRASKRABA, M. eds. Theoretical Reservoir and its applications Leiden, Backhuys Publishers, p. 227-265.

Agostinho, A. A.; Gomes, L. C. \& Pelicice, F. M. 2007. Ecologia e manejo de recursos pesqueiros em reservatórios do Brasil. Maringá, EDUEM. 501p.

Agostinho, A. A.; Gomes, L. C.; Santos, N. C. L.; Ortega, J. C. G. \& Pelicice, F. M. 2015. Fish assemblages in Neotropical reservoirs: colonization patterns, impacts and management. Fisheries Research 173:26-36.

Albrecht, M. P. \& Caramaschi, E. P. 2003. Feeding ecology of Leporinus friderici (Teleostei, Anostomidae) in the Upper Tocantins river, Central Brazil, before and after installation of a hydroelectric plant. Studies on Neotropical Fauna and Environment 38:33-40.

Araújo-Lima, C. A. R. M.; Agostinho, A. A. \& Fabré, N. N. 1995. Trophic aspects of fish communities in Brazilian rivers and reservoirs. In: Tundisi, J. G.; Bicudo, C. E. M.; Matsumura-Tundisi, T. eds. Limnology in Brazil. Rio de Janeiro, ABC/SBL, p. 105-136.

Balassa, G. C.; Fugi, R.; Hahn, N. S. \& Galina, A. B. 2004. Dieta de espécies de Anostomidae (Teleostei, Characiformes), na área de influência do reservatório de Manso, Mato Grosso, Brasil. Iheringia, Série Zoologia 94(1):77-82. http://dx.doi.org/10.1590/S007347212004000100014

BALON, E. K. 1973. Results of fish population size assessments in Lake Kariba coves (Zambia), a decade after their creation. In: ACKERMANN, W. C.; White, G. F.; Worthington, E. B. \& Ivens, J. L. eds Manmade lakes: their problems and environmental effects. Washington, DC, American Geophysical Union, p. 149-158.

BatagelJ, V. \& Mrvar, A. 1998. PAJEK - program for large network analysis. Connection 21:47-57.

BAXTER, R. M. 1977. Environmental effects of dams and impoundments. Annual Review in Ecology and Systematics 8:255-283. https://doi. org/10.1146/annurev.es.08.110177.001351

Bennemann, S. T.; Galves, W. \& CAPRA, L. G. 2011. Recursos alimentares utilizados pelos peixes e estrutura trófica de quatro trechos no reservatório Capivara (Rio Paranapanema). Biota Neotropica 11(1):6371. http://dx.doi.org/10.1590/S1676-06032011000100006

Cassemiro, F. A. S.; Hahn, N. S. \& Delariva, R. L. 2005. Estrutura trófica da ictiofauna ao longo do gradiente longitudinal do reservatório de Salto Caxias (rio Iguaçu, Paraná, Brasil), no terceiro ano após o represamento. Acta Scientiarum, Biological Sciences 27:63-71. http:// dx.doi.org/10.4025/actascibiolsci.v27i1.1362
CRIPPA, V. E. L. \& HAHN, N. S. 2006. Use of resources by the fish fauna of a small reservoir (Rio Jordão, Brazil) before and shortly after its filling. Neotropical Ichthyology 4(3):357-362. http://dx.doi.org/10.1590/ S1679-62252006000300007

Cunha-Santino, M. B.; Bitar, A. L. \& Bianchini JR, I. 2013. Chemical constraints on new man-made lakes. Environmental Monitoring and Assessment 185:10177-10190. http://dx.doi.org/10.1007/s10661013-3322-0.

Dias, A. C. M. I.; Branco, C. W. C. \& Lopes, V. G. 2005. Estudo da dieta natural de peixes no reservatório de Ribeirão das Lajes, Rio de Janeiro, Brasil. Acta Scientiarum, Biological Sciences 27 (4):355-364. http:// dx.doi.org/10.4025/actascibiolsci.v27i4.1270

Gaspar da Luz, K. D.; Abujanra, F.; Agostinho, A. A. \& Gomes, L. C. 2001. Caracterização trófica da ictiofauna de três lagoas da planície aluvial do alto rio Paraná, Brasil. Acta Scientiarum, Biological Sciences 23(2):401-407.

Goulding, M. 1980. The fishes and the forest: explorations in amazon natural history. Berkeley, University of California Press. 250p.

Hahn, N. S.; Agostinho, A. A.; Gomes, L. C. \& Bini, L. M. 1998. Estrutura trófica da ictiofauna do reservatório de Itaipu (Paraná-Brasil) nos primeiros anos de sua formação. Interciência 23(5):299-305.

HahN, N. S. \& Fugi, R. 2007. Alimentação de peixes em reservatórios brasileiros: alterações e consequências nos estágios iniciais do represamento. Oecologia Brasiliensis 11(4):469-480.

HAHN, N. S.; Fugi, R.; ALMEIDA, V. L. L.; RuSSO, M. R. \& LOUREIRO-CRIPPA, V. E. 1997. Dieta e atividade alimentar de peixes do reservatório de segredo. In: Agostinho, A. A. \& Gomes, L. C. eds. Reservatório de Segredo: bases ecológicas para o manejo. Maringá, Eduem, p. 41-162.

Henry, R. 1992. The oxygen deficit in Jurumirim Reservoir (Paranapanema river, São Paulo, Brazil). Japanese Journal of Limnology 53:379-384.

HenRY, R. 2003. Estudo de aplicação em Lagoas marginais ao Rio Paranapanema na zona de sua desembocadura na Represa de Jurumirim. In: HENRY, R. ed. Ecótonos nas interfaces dos ecossistemas aquáticos. São Carlos, RiMA Editora, p. 1-128.

Henry, R. \& Nogueira, M. G. 1999. A represa de Jurumirim (São Paulo): Primeira síntese sobre o conhecimento limnológico. In: HENRY, R. ed. Ecologia de reservatórios: estrutura, função e aspectos sociais. Botucatu, FUNDIBIO, FAPESP, p. 651-686.

Henry, R.; Panarelli, E. A.; Casanova, S. M. C.; Suiberto, M. R. \& Afonso, A. A. 2006. Interações hidrológicas entre lagoas marginais e o rio Paranapanema na zona de sua desembocadura na represa de Jurumirim. In: Nogueira, M.G.; HenRY, R. \& JorCin, A. eds. Ecologia de reservatórios: Impactos potenciais, ações de manejo e sistema em cascata. São Carlos, Editora RiMA, p. 57-82.

HILl, M. O. \& GaUCH, H. G. 1980. Detrended correspondence analysis: an improved ordination technique. Vegetatio 42:47-58. http://dx.doi. org/10.1007/BF00048870

KAWAKAMI, E. \& VAZzolER, G. 1980. Método gráfico e estimativa de índice alimentar aplicado no estudo de alimentação de peixes. Boletim do Instituto Oceanográfico 29(2):205-207. http://dx.doi.org/10.1590/ S0373-55241980000200043

Kimmel, B. L. \& Groeger, A. W. 1986. Limnological and ecological changes associated with reservoir aging. In: HALL, G. E. \& VAN DEN AvYLE, M. J. eds. Reservoir fisheries management: strategies for the 80's. Bethesda, Reservoir Committee, Southern Division, American Fisheries Society, p. 103-109.

Lowe-McConnell, R. H. 1999. Estudos ecológicos de comunidades de peixes tropicais. São Paulo, EDUSP. 535p.

Luz-Agostinho, K. D. G.; Bini, L. M.; Fugi, R.; Agostinho, A. A. \& JUlio JR., H. F. 2006. Food spectrum and trophic structure of the ichthyofauna of Corumbá Reservoir, Paraná river basin, Brazil. Neotropical Ichthyology 4(1):61-68. http://dx.doi.org/10.1590/S167962252006000100005

McCune, B. \& MefFord, M. J. 2006. PC-ORD - Multivariate Analysis of Ecological Data. Version 5.31. Gleneden Beach, MjM Software.

Mérona, B.; Dos-Santos, G. M. \& Almeida, R. G. 2001. Short term effects of Tucurui Dam (Amazonia, Brazil) on the trophic organization of fish communities. Environmental Biology Fishes 60:375-392. http:// dx.doi.org/10.1023/A:1011033025706 
Mérona, B.; Vigouroux, R. \& Horeau, V. 2003. Changes in food resources and their utilization by fish assemblages in a large tropical reservoir in South America (Petit-Saut Dam, French Guiana). Acta Oecologica 24:147-156. http://dx.doi.org/10.1016/S1146-609X(03)00065-1

Mol, J. H.; Mérona, B.; Ouboter , P. E. \& Sahdew, S. 2007. The fish fauna of Brokopondo Reservoir, Suriname, during 40 years of impoundment. Neotropical Ichthyology 5:351-368. http://dx.doi.org/10.1590/S167962252007000300015

Monteiro, A. S.; Oliveira, A. H. M. \& Pelicice, F. M. 2009. Alterações espaciais na estrutura trófica da ictiofauna: Sucessos e insucessos na colonização do reservatório. In: Agostinho, C. S.; Pelicice, F. M. \& MArques, E. E. eds. Reservatório de Peixe Angical: Bases ecológicas para o manejo da ictiofauna. São Carlos, Editora RiMA, p. 77-86.

NeIFF, J. J. 1999. El regimen de pulsos en rios y grandes humedales de Sudamérica. In: Malvarez, A. I. \& Kandus, P. eds. Topicos sobre grandes humedales sudamericanos. Montevideo, MVD: ORCYTMAB (Unesco), p. 97-145.

Nogueira, M. G.; Henry, R. \& Maricatto, F. E. 1999. Spatial and temporal heterogeneity in the Jurumirim reservoir, São Paulo, Brazil. Lakes \& Reservoir: Research and Management 4:107-120. http://dx.doi. org/10.1046/j.1440-1770.1999.00086.x

Novaes, J. L. C.; Caramaschi, E. P. \& Winemiller, K. O. 2004. Feeding of Cichla monoculus Spix, 1829 (Teleostei: Cichlidae) during and after reservoir formation in the Tocantins river, Central Brazil. Acta Limnologica Brasiliensia 16 (1):41-49.

Orsi, M. L. \& BRITtON, J. R. 2014. Long-term changes in the fish assemblage of a neotropical hydroelectric reservoir. Journal of Fish Biology 84:1964-1970. http://dx.doi.org/10.1111/jfb.12392

Petrere-Junior, M. 1996. Fisheries in large tropical reservoirs in South America. Lakes \& Reservoirs: Research and Management 2:111133. http://dx.doi.org/10.1111/j.1440-1770.1996.tb00054.x

PIET, G. J. 1998. Impact of environmental perturbation on a tropical fish community. Journal of Fisheries Aquatic Sciences 55:1842-1853. http://dx.doi.org/10.1139/f98-073

Ribeiro, A. R.; Biagioni, R. C. \& Smith, W. S. 2014. Estudo da dieta natural da ictiofauna de um reservatório centenário, São Paulo, Brasil. Iheringia, Série Zoologia 104(4):404-412. http://dx.doi. org/10.1590/1678-476620141044404412
RoDríGuez-Ruiz, A. 1998. Fish species composition before and after construction of a reservoir on the Guadalete river (SW Spain). Archiv für Hydrobiologie 142(3):353-369. http://dx.doi.org/10.1127/archivhydrobiol/142/1998/353

SAMPAIO, T. 1944. Relatório sobre os estudos efetuados nos rios Itapetininga e Paranapanema. Revista do Instituto Geográfico e Geológico 2(3):30-81.

Schneider, M.; Aquino, P. P. U; Silva, M. J. M. \& Fonseca, C. P. 2011. Trophic structure of a fish community in Bananal stream subbasin in Brasília National Park, Cerrado biome (Brazilian Savanna), DF. Neotropical Ichthyology 9(3):579-592. http://dx.doi.org/10.1590/ S1679-62252011005000030

Souto, A. C.; Lima, F. P.; Gildo, N. M. \& Vidotto-Magnoni, A. P. 2016. Dieta das espécies de peixes do reservatório de Jurumirim e seus principais tributários. In: SILVA, R. J. ed. Integridade ambiental da represa de Jurumirim ictiofauna e relações ecológicas. São Paulo, Unesp, p. 95-114.

Tundisi, J. G. 1993. Represas do Paraná superior: limnologia e bases científicas para o gerenciamento. In: Boltovskoy, A. \& LóPez, H. L. eds. Conferências de limnología. La Plata, Instituto de Limnologia "Dr. R. A. Ringuelet", p. 41-52.

Vidotto-Magnoni, A. P. \& Carvalho, E. D. 2009. Aquatic insects as the main food resource of the fish community in a Neotropical reservoir. Neotropical Ichthyology 7:701-708. http://dx.doi.org/10.1590/S167962252009000400020

Williams, J. D.; Winemiller, K. O.; TAPhorn, D. C. \& Balbas, L. 1998. Ecology and status of piscivores in Guri, an oligotrophic tropical reservoir. North American Journal of Fisheries Management 18(2):274-285.

Winemiller, K. O. \& Kelso-Winemiller, L. C. 1996. Comparative ecology of catfishes of the upper Zambezi river floodplain. Journal of Fish Biology 49(6):1043-1061. http://dx.doi.org/10.1111/j.1095-8649.1996. tb01777.x

Ximenes, L. Q. L.; Mateus, L. A. F. \& Penha, J. M. F. 2011. Variação temporal e espacial na composição das guildas alimentares da ictiofauna em lagoas marginais do Rio Cuiabá, Pantanal Norte. Biota Neotropica 11(1):205-215. http://dx.doi.org/10.1590/S16760603201100010002 